\title{
'Candidatus Liberibacter asiaticus' Encodes a Functional Salicylic Acid (SA) Hydroxylase That Degrades SA to Suppress Plant Defenses
}

\author{
Jinyun Li, Zhiqian Pang, Pankaj Trivedi, Xiaofeng Zhou, Xiaobao Ying, Hongge Jia, and Nian Wang \\ Citrus Research and Education Center, Department of Microbiology and Cell Science, University of Florida, 700 Experiment \\ Station Road, Lake Alfred, FL 33850, U.S.A.
}

Accepted 24 April 2017.

\begin{abstract}
Pathogens from the fastidious, phloem-restricted 'Candidatus Liberibacter' species cause the devastating Huanglongbing (HLB) disease in citrus worldwide and cause diseases on many solanaceous crops and plants in the Apiaceae family. However, little is known about the pathogenic mechanisms due to the difficulty in culturing the corresponding ' $\mathrm{Ca}$. Liberibacter' species. Here, we report that the citrus HLB pathogen ' $\mathrm{Ca}$. L. asiaticus' uses an active salicylate hydroxylase SahA to degrade salicylic acid (SA) and suppress plant defenses. Purified SahA protein displays strong enzymatic activity to degrade $\mathrm{SA}$ and its derivatives. Overexpression of SahA in transgenic tobacco plants abolishes $\mathrm{SA}$ accumulation and hypersensitive response (HR) induced by nonhost pathogen infection. By degrading SA, ' $\mathrm{Ca}$. L. asiaticus' not only enhances the susceptibility of citrus plants to both nonpathogenic and pathogenic Xanthomonas citri but also attenuates the responses of citrus plants to exogenous SA. In addition, foliar spraying of 2,1,3-benzothiadiazole and 2,6-dichloroisonicotinic acid, SA functional analogs not degradable by SahA, displays comparable (and even better) effectiveness with $\mathrm{SA}$ in suppressing ' $\mathrm{Ca}$. L. asiaticus' population growth and HLB disease progression in infected citrus trees under field conditions. This study demonstrates one or more pathogens suppress plant defenses by degrading SA and establish clues for developing novel SA derivativesbased management approaches to control the associated plant diseases.
\end{abstract}

Plant immunity responses involve the perception of the invading pathogen and the activation of specific defense signal transduction pathways that lead to activation of pathogenassociated molecular pattern (PAMP)-triggered immunity (PTI), effector-triggered immunity (ETI), and systemic acquired resistance (SAR) (Jones and Dangl 2006). Salicylic acid (SA) and its derivatives play a central role in plant defense by mediating responses against pathogens in many plant species, and they are important for activating PTI, ETI, and SAR (An and Mou 2011; Vlot et al. 2009). SA is an endogenous defense signal and its derivative, methyl

J. Li, Z. Pang, and P. Trivedi contributed equally to this work.

Corresponding author: Nian Wang; E-mail: nianwang@ufl.edu

*The $\boldsymbol{e}$-Xtra logo stands for "electronic extra" and indicates that six supplementary figures and two supplementary tables are published online.

(c) 2017 The American Phytopathological Society salicylate (MeSA), is one of the signals for SAR (Fu and Dong 2013; Park et al. 2007). Bacterial PAMPs, such as flg22, induce SA production (Mishina and Zeier 2007; Tsuda et al. 2008). SA may be synthesized from the phenylpropanoid pathway or via isochorismate synthase, as demonstrated in Arabidopsis thaliana, tobacco (Nicotiana benthamiana), and tomato (Chen et al. 2009; Wildermuth et al. 2001). SA has been shown to be synthesized in the chloroplast (Fragnière et al. 2011) and transported systemically via the phloem (Métraux et al. 1990; Molders et al. 1996). In addition to plant defense, SA is involved in a variety of physiological responses, such as stomatal closure (Mori et al. 2001; Sun et al. 2010), senescence (Morris et al. 2000), cell growth (Vanacker et al. 2001), thermotolerance (Clarke et al. 2004), and seed germination (Lee et al. 2010).

Interestingly, many bacteria, e.g., members of genera Pseudomonas, Ralstonia, Bacillus, Agrobacterium, Rhizobium, Sinorhizobium, and Burkholderia, encode SA hydroxylases that metabolize SA. SA hydroxylase is a flavoprotein monooxygenase and a proximal component of the naphthalene degradation pathway. In brief, SA hydroxylase binds SA and NADH or NADPH to form an enzyme-substrate complex and, then, molecular oxygen binds to the complex for the production of catechol, $\mathrm{CO}_{2}$, and $\mathrm{H}_{2} \mathrm{O}$. SA hydroxylase has been studied closely in several naphthalene-degrading bacteria, e.g., Pseudomonas putida (You et al. 1990, 1991), P. cepacia and P. stutzeri (Bosch et al. 1999). In these bacteria, SA is produced as an intermediate in the degradation of naphthalene and is converted by SA hydroxylase to catechol. Interestingly, it has been reported that Ralstonia solanacearum degrades plant SA to protect itself from inhibitory levels of this compound and, also, to enhance its virulence on plant hosts (Lowe-Power et al. 2016). SA hydroxylases have also been reported from several fungi, including the smut fungus Ustilago maydis (Rabe et al. 2013) and the cool season grass fungal endophyte Epichlö festucae (Ambrose et al. 2015). Remarkably, expressing bacterial SA hydroxylase in plants abolishes plant defense by degrading SA. For example, Arabidopsis plants carrying the $n a h G$ gene that encodes a salicylate hydroxylase are defective in SAR induced by $P$. syringae pv. tomato DC3000 avrRpt2 against infection by the fungal pathogen Peronospora parasitica (Lawton et al. 1995). Considering the central role of SA in plant defenses, bacteria might utilize SA hydroxylase to suppress plant defense responses to establish infection.

The fastidious gram-negative, obligate parasite, phloemlimited, and insect-vectored $\alpha$-proteobacteria 'Candidatus Liberibacter' species have emerged among the most damaging pathogens to agriculture. For example, ' $\mathrm{Ca}$. L. asiaticus' and ' $\mathrm{Ca}$. L. solanacearum' cause citrus Huanglongbing 
(HLB) disease (Gottwald 2010) and potato zebra chip disease (Lin and Gudmestad 2013), respectively, which are presenting a major threat to the citrus and potato industries in the United States and other citrus- and potato-production regions in the world (Bové 2006; Lin and Gudmestad 2013; Wang and Trivedi 2013). HLB is the most devastating disease affecting citrus worldwide (Bové 2006; Wang and Trivedi 2013). No currently available approach is able to effectively control HLB. ' $\mathrm{Ca}$. L. asiaticus' is the most aggressive HLB pathogen among the HLB-associated 'Candidatus Liberibacter' species, i.e., 'Ca. L. asiaticus', ' $C a$. L. africanus', and ' $C a$. L. americanus', and its vector is the Asian citrus psyllid (Diaphorina citri). ' $\mathrm{Ca}$. L. asiaticus' is limited to two distinct hosts, plants, mainly citrus and its close relatives, and psyllids, and it has not been cultured in medium (Bové 2006; Wang and Trivedi 2013). 'Ca. L. asiaticus' can infect all citrus species and hybrids and eventually results in tree death (Bové 2006; Gottwald 2010). HLB was found in Brazil in 2004 (Gottwald et al. 2007) and in the United States in 2005 (Halbert 2005). HLB is currently destroying the Florida citrus industry with dramatic destructive effects on society, the economy, and ecology. HLB has played a key role in the loss of about 100,000 citrus acres since 2007 in Florida. It was estimated that HLB has cost Florida's economy approximately $\$ 3.6$ billion in lost revenues and 6,611 jobs since 2006 (Alvarez et al. 2016). Methods to counteract the virulence strategy of ' $\mathrm{Ca}$. L. asiaticus' and control HLB are being urgently studied in order to learn how to reduce its destructive effect.

Pathogenicity and virulence factors of ' $\mathrm{Ca}$. L. asiaticus' remain largely unknown, although the availability of complete genome sequences of different ' $\mathrm{Ca}$. L. asiaticus' "strains" from Florida (Duan et al. 2009), China (Lin et al. 2013), and Japan (Katoh et al. 2014) makes functional genomics investigations possible. Recent studies revealed that the ATP translocase in ' $\mathrm{Ca}$. L. asiaticus' is involved in direct ATP/ADP importation from its host cells and enables the bacterium to act as an "energy parasite" (Vahling et al. 2010) and that two prophageencoded autotransporter proteins of ' $\mathrm{Ca}$. L. asiaticus' target the mitochondria in tobacco (Hao et al. 2013). In addition, the transcriptional activator $\mathrm{LdtR}$ in ' $\mathrm{Ca}$. L. asiaticus' was demonstrated to mediate osmotic stress tolerance and may contribute to survival of the pathogen within the phloem of a citrus tree (Pagliai et al. 2014). The peroxidase SC2_gp095 encoded in a prophage of ' $\mathrm{Ca}$. L. asiaticus' was found to be a secreted effector suppressing plant defenses through detoxification of $\mathrm{H}_{2} \mathrm{O}_{2}$ (Jain et al. 2015). Recently, transient expression studies showed that the ' $\mathrm{Ca}$. L. asiaticus' effector protein CLas $5315 \mathrm{mp}$ (mature protein) was localized in the chloroplast and induced strong callose deposition and cell death at 3 days postinoculation (dpi) in tobacco ( $N$. benthamiana) (Pitino et al. 2016). Other studies with the examination of citrus transcriptomes in response to ' $\mathrm{Ca}$. L. asiaticus' infection and comparative transcriptome and proteomics analyses have revealed that ' $\mathrm{Ca}$. $\mathrm{L}$. asiaticus' actively alters molecular processes in citrus (Albrecht and Bowman 2012; Aritua et al. 2013; Kim et al. 2009; Liao and Burns 2012; Nwugo et al. 2013; Rawat et al. 2015; Zhong et al. 2015). However, knowledge about the molecular mechanisms of pathogenicity and virulence of ' $C a$. L. asiaticus' is essentially limited. In addition, ' $C a$. Liberibacter' species are known to induce plant defenses, e.g., activation of the SA pathway (Mann et al. 2012), probably resulting from recognition of the PAMPs, e.g., lipopolysaccharides (LPS) and flagella, even though the mechanistic understanding of the process remains unknown (Wang and Trivedi 2013). How ' $C a$. Liberibacter' species deal with plant defenses remains unknown.
The genomes of all sequenced pathogenic ' $\mathrm{Ca}$. Liberibacter' spp. each contain a putative SA hydroxylase encoding gene (Duan et al. 2009; Lin et al. 2013; Katoh et al. 2014; Wulff et al. 2014), and the homologs share relatively high similarities (discussed below). This implies that the SA hydroxylase might play an important role in pathogen-plant interactions by suppressing plant defenses. In the present study, we aimed to characterize the SA hydroxylase (CLIBASIA_00255) encoded by ' $C a$. L. asiaticus', herein named SahA (SA hydroxylase of ' $C a$. L. asiaticus'). We hypothesized that ' $C a$. L. asiaticus' encodes a functional SA hydroxylase that degrades SA and suppresses plant defenses. To neutralize the degrading effect of SA hydroxylase on SA, we applied SA analogs and investigated their effect on the control of citrus HLB.

\section{RESULTS}

$\operatorname{SahA}$ is upregulated in citrus relative to insect host.

The sahA (CLIBASIA_00255) gene consists of a single transcriptional unit and encodes the only putative SA hydroxylase in the genome of the ' $\mathrm{Ca}$. L. asiaticus'strain psy62 (Duan et al. 2009). To evaluate the expression levels of sahA in different infected hosts, reverse transcription-quantitative polymerase chain reaction (RT-qPCR) was performed in ' $\mathrm{Ca}$. L. asiaticus'-infected citrus and psyllids. Comparative expression analyses revealed that $\operatorname{sah} A$ is significantly upregulated in citrus relative to psyllids. In Valencia sweet orange, the levels of expression of $\operatorname{sah} A$ were around 3.5 -fold higher than in psyllids $(P<0.05$, Student $t$ test $)$ (Fig. 1).

\section{SahA encodes a functional SA hydroxylase.}

The putative SA hydroxylase SahA shares high amino acid sequence identity to homologs found in ' $\mathrm{Ca}$. Liberibacter' species, including ' $\mathrm{Ca}$. L. africanus' (74\%), ' $\mathrm{Ca}$. L. solanacearum' (68\%), and 'Ca. L. americanus' (57\%) (Fig. 2A). SahA also shares certain amino acid sequence identity to its homologs in Liberibacter crescens (47\%) and other members of the Rhizobiaceae family, including Rhizobium leguminosarum (40\%), Sinorhizobium fredii (38\%), and Agrobacterium tumefaciens (38\%). None of these proteins has previously been characterized. SahA was also similar to the well-characterized salicylate hydroxylases encoded by $n a h G$ genes from $P$. putida and $P$. stutzeri, which are flavoprotein hydroxylases, and the FAD and NADH binding sites and proposed substrate active sites have been identified (Bosch et al. 1999; Eppink et al. 1997). These motifs in the ' $\mathrm{Ca}$. L. asiaticus' putative

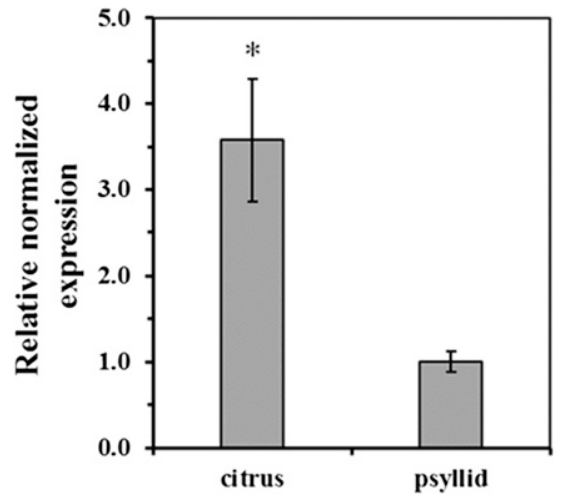

Fig. 1. Relative expression of the $s a h A$ gene in citrus and psyllids. Relative transcript abundance of $\operatorname{sah} A$ was normalized against its expression in 'Candidatus Liberibacter'-infected psyllids. Bars represent average \pm standard error of the means. Asterisks represent significant differences in the transcript abundance between different hosts $(P<0.05$, Student $t$ test $)$ 
SA hydroxylase SahA are well conserved relative to the $P$. putida NahG (Fig. 2B).

Due to the inability to culture and genetically manipulate ' $\mathrm{Ca}$. L. asiaticus', we purified the SahA protein from Escherichia coli cells overexpressing $\operatorname{sahA}$ and tested its SA hydroxylase activity. The SahA protein was purified as a maltose-binding protein (MBP) (42.5 kDa) and His-tagged protein, using Ni-NTA agarose (Qiagen, Valencia, CA, U.S.A.) with a molecular mass of $90.5 \mathrm{kDa}$, similar to the predicted molecular mass of the MBP and His-tagged SahA protein (Supplementary Fig. S1). The purified SahA was then cleaved from MBP and was subjected to assays for SA hydroxylase activity. Functional activity of SahA was determined by quantification of the rate of NADH oxidation along with enzymatic degradation of SA in a spectrophotometric assay. The purified SahA displayed a strong SA hydroxylase activity $(3,974 \pm 171$ nanomoles of NADH per minute per milligram of protein), while the bovine serum albumin (BSA) that served as a negative control did not show SA hydroxylase activity $(20.8 \pm 49.6$ nanomoles of NADH per minute per milligram of protein). The enzymatic activity of SahA is comparable with the well-characterized SA hydroxylases of NahG and NahW from P. stutzeri (Bosch et al. 1999). Thus, SahA is a functional SA hydroxylase.

We further assessed the specificity of the SahA enzyme on various substrates, including SA derivatives and its functional analogs, i.e., the SAR inducers 2,1,3-benzothiadiazole
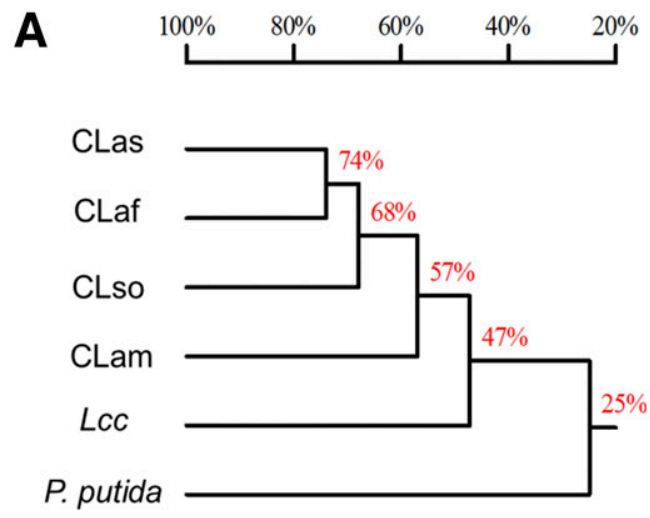

B

CLas
CLaf
CLso
CLam
LcC
P. putida
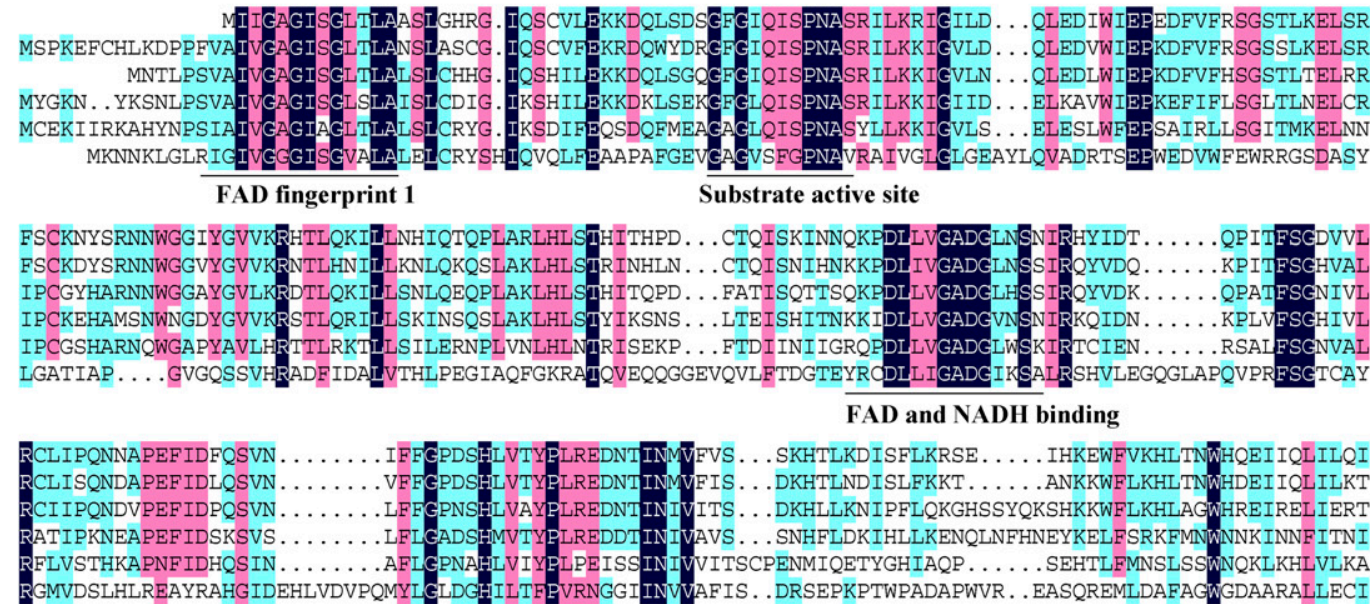

\section{FAD and NADH binding}

CLas
CLaf
CLso
CLam
LcC
P. putida

CLas
CLaf
CLso
CLam
LcC
P. putida

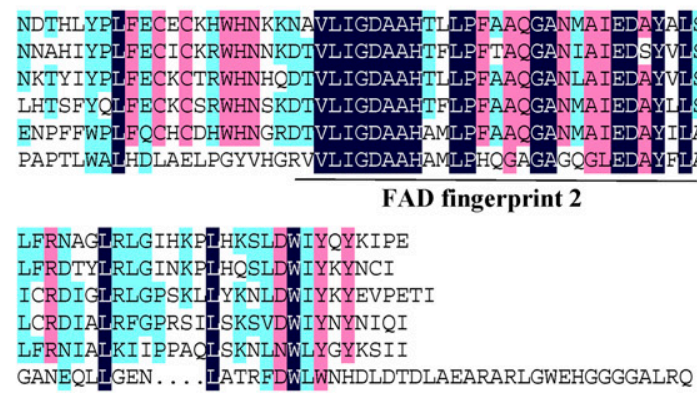

CLas
CLaf
CLso
CLam
LcC
P. putida

Fig. 2. Comparison of deduced salicylate hydroxylase amino acid sequences from 'Candidatus Liberibacter' species and Pseudomonas putida. A, Homology tree of deduced salicylate hydroxylase amino acid sequences from 'Ca. Liberibacter' species and Pseudomonas putida. CLas = 'Ca. L. asiaticus' (National Center for Biotechnology Information accession number ACT56641), CLaf = ' $C a$. L. africanus' (accession number WP_047264462), CLso = 'Ca. L. solanacearum' (accession number KJZ81788), CLam = 'Ca. L. americanus' (accession number EMS36599), Lcc $=$ Liberibacter crescens (accession number WP_015273300), P. putida = Pseudomonas putida (accession number AAA25897). B, Alignment of deduced salicylate hydroxylase amino acid sequences from 'Ca. Liberibacter' species and Pseudomonas putida. The conserved functional motifs, i.e., the FAD and NADH binding sites and proposed substrate active sites are highlighted in dark background and underlined. 
(BTH) and 2,6-dichloroisonicotinic acid (INA). SahA was able to degrade methylsalicylates (3-methylsalicylate and 4-methylsalicylate) and chlorosalicylates (3-chlorosalicylate and 5-chlorosalicylate) (Table 1). However, the relative rates by which the individual SA derivatives were degraded differed significantly (Table 1). These observations were consistent with the previous report on $\mathrm{NahG}$ and NahW from P. stutzeri (Bosch et al. 1999). Not surprisingly, SahA did not degrade BTH or INA, as its structure is different from SA (Supplementary Fig. S2). Thus, SahA appears to have restricted substrate specificities against $\mathrm{SA}$ and its derivatives.

\section{Expression of SahA in tobacco suppresses hypersensitive response (HR) induced by the nonhost pathogen Xanthomonas citri subsp. citri A306.}

Tobacco is resistant to the nonhost pathogen $X$. citri subsp. citri and displays typical HR following inoculation of $X$. citri A306 derivatives overexpressing the $h r p X$ gene (X. citri A306 [p53-HrpX]) (Zhou et al. 2016). To assess the functional activity of SahA in planta, transgenic tobacco plants expressing the $\operatorname{sah} A$ gene were established and inoculated with bacterial cells of $X$. citri A306 (p53-HrpX) via leaf infiltration. At $48 \mathrm{~h}$ after inoculation, no HR phenotypes were observed in transgenic SahA plants, whereas, in wild-type plants, the leaves

Table 1. Enzymatic activity of the purified salicylate hydroxylase SahA

\begin{tabular}{|c|c|c|}
\hline Compound & Enzymatic activity $^{\mathbf{y}}$ & $\begin{array}{c}\text { Relative } \\
\text { activity }(\%)^{\mathrm{z}}\end{array}$ \\
\hline Salicylate & $3,974 \pm 171$ & 100 \\
\hline 3-Methylsalicylate & $3,026 \pm 152$ & 76.1 \\
\hline 4-Methylsalicylate & $3,101 \pm 225$ & 78.0 \\
\hline 3-Chlorosalicylate & $2,696 \pm 165$ & 67.8 \\
\hline 5-Chlorosalicylate & $2,559 \pm 158$ & 64.4 \\
\hline 2,1,3-Benzothiadiazole & $34.6 \pm 38.1$ & 0 \\
\hline 2,6-Dichloroisonicotinic acid & $10.8 \pm 17.6$ & 0 \\
\hline
\end{tabular}

y Enzymatic activities are the means of triplicate assays \pm standard deviation and are presented in nanomoles NADH per minute per milligram of protein.

${ }^{\mathrm{z}}$ Relative activity was calculated by determining the substrate-dependent $\Delta \mathrm{OD}_{340} / \mathrm{min}$, resulting from the conversion of $\mathrm{NADH}$ to $\mathrm{NAD}$, and comparing values obtained to those obtained with salicylate as substrate. displayed rapid cell death at inoculated area, characteristic of HR against $X$. citri infection (Fig. 3A). Consistent with these observations, $X$. citri bacterial population had rapidly and significantly declined in the inoculated area of wild-type plants, at $24 \mathrm{~h}$ after inoculation, while no decline of $X$. citri population occurred in transgenic SahA plants (Fig. 3B). Additionally, in wild-type plants, the content of SA significantly increased in the inoculated leaves; by contrast, the content of SA did not increase in inoculated leaves of transgenic SahA plants (Fig. 3C). These results indicated that SahA was effective in degrading endogenous SA in plants, thereby attenuating SA accumulation and abolishing HR in transgenic SahA plants against $X$. citri infection.

\section{' $\mathrm{Ca}$. L. asiaticus' infection affects SA accumulation, pathogenesis-related (PR) gene expression, and susceptibility of citrus against $X$. citri.}

Because degradation of SA has been reported in the suppression of plant defense responses, we hypothesized that ' $\mathrm{Ca}$. L. asiaticus' infection will decrease the expression of defenserelated genes in citrus as the bacterium codes for an active SA hydroxylase. To test our hypothesis, X. citri $\mathrm{A}^{\mathrm{W}} 12879$, which causes the HR on grapefruit (Citrus paradisi Macf.) and is nonpathogenic on sweet orange (C. sinensis Osb.) (Egel et al. 1991; Rybak et al. 2009), was used to inoculate ' $\mathrm{Ca}$. L. asiaticus'infected and healthy plants of Duncan grapefruit and Valencia sweet orange. We then monitored the accumulation of $P R$ gene transcripts and the production of SA in ' $\mathrm{Ca}$. L. asiaticus'-infected and healthy leaves of both citrus varieties. For the expression of $P R$ genes, we tested the expression of the $P R-1, P R-2$, and $P R-5$ genes, considered as markers of SA-dependent SAR (Fu and Dong 2013; Molinari et al. 2014). The expression of the $P R$ genes increased after $X$. citri $\mathrm{A}^{\mathrm{W}}$ inoculation in both healthy and ' $C a$. L. asiaticus'-infected leaves of both citrus varieties. However, the expression level of all three $P R$ genes was significantly lower in the ' $C a$. L. asiaticus'-infected leaves as compared with healthy leaves in both citrus varieties when challenged with $X$. citri $\mathrm{A}^{\mathrm{W}}$ (Fig. 4A; Supplementary Fig. S3) at 48 and $72 \mathrm{~h}$ postinoculation. These data indicate that ' $\mathrm{Ca}$. L. asiaticus' infection suppresses the mRNA levels of $P R$ genes during secondary infection of citrus with $X$. citri $\mathrm{A}^{\mathrm{W}}$.
A

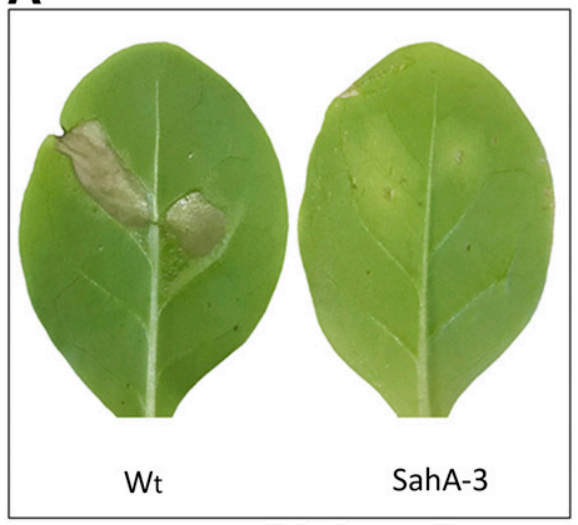

B

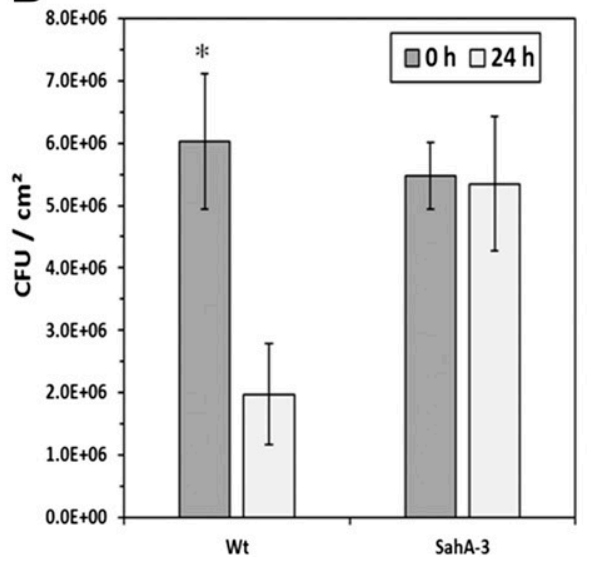

C

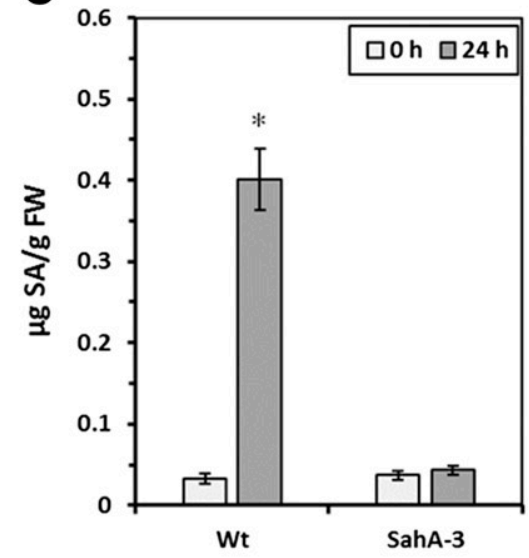

Fig. 3. Expression of salicylate hydroxylase SahA in transgenic tobacco plants attenuated hypersensitive response (HR) and salicylic acid (SA) accumulation against nonhost pathogen Xanthomonas citri. A, Hypersensitive response (HR) induction on Nicotiana tabacum. X. citri A306 (p53-HrpX) cells were inoculated in 4-week-old fully expanded leaves of tobacco by infiltration with a needleless syringe at the concentration of $10^{8} \mathrm{CFU}$ per milliliter. HR inductions were observed and photographed at $48 \mathrm{~h}$ postinoculation. Wt $=$ wild-type $N$. tabacum with empty vector pERGFP-1380N, SahA-3 = the transgenic line SahA-3. B, Populations of X. citri A306 (p53-HrpX) recovered from leaf tissue of the inoculated area, recorded as CFU per square millimeter of leaf tissue, mean \pm standard error (SE). C, Amounts of SA extracted from leaf tissues of the $X$. citri A306 (p53-HrpX)-inoculated plants, recorded as micrograms of SA per gram of fresh leaf tissue, mean \pm SE. Asterisks represent significant differences in amounts between different time points $(P<0.05$, Student $t$ test $)$. 
We also measured the SA accumulation in ' $\mathrm{Ca}$. L. asiaticus'infected and healthy leaves of Valencia sweet orange and Duncan grapefruit following inoculation with $X$. citri $\mathrm{A}^{\mathrm{W}}$. The SA content of ' $\mathrm{Ca}$. L. asiaticus'-infected leaf samples was significantly lower than that of the healthy samples for both citrus varieties at 48 and $72 \mathrm{~h}$ after inoculation (Fig. 4B). The production of SA was greater in Duncan grapefruit as compared with Valencia sweet orange (Fig. 4B). The amount of SA in the leaf samples correlated well with the expression of $P R$ genes in both citrus varieties. Our data suggest that ' $\mathrm{Ca}$. L. asiaticus' infection modulates SA accumulation and the regulation of $P R$ genes in citrus in response to subsequent $X$. citri $\mathrm{A}^{\mathrm{W}}$ inoculation.

We further hypothesized that reduced SA accumulation and $P R$ gene expression would enhance the susceptibility of citrus plants to infection by one or more secondary pathogens. To test this hypothesis, we monitored the population dynamics of two citrus pathogens, $X$. citri A306 and X. citri $\mathrm{A}^{\mathrm{W}} 12879$ strains in ' $C a$. L. asiaticus'-infected and healthy leaves of grapefruit at different time intervals. On grapefruit, X. citri A306 is pathogenic, whereas $X$. citri $\mathrm{A}^{\mathrm{W}} 12879$ is nonpathogenic. The data showed that ' $\mathrm{Ca}$. L. asiaticus' infection facilitated the growth of strains $X$. citri A306 and $X$. citri A ${ }^{\mathrm{W}} 12879$ in ' $C a$. L. asiaticus'-infected tissue. Higher titers of $X$. citri A306 and $X$. citri $\mathrm{A}^{\mathrm{W}} 12879$ were observed in the ' $\mathrm{Ca}$. L. asiaticus'infected leaves as compared with healthy leaves at different time points after inoculation (Fig. 5). The results indicated that ' $\mathrm{Ca}$. L. asiaticus' infection made citrus more susceptible to infection by secondary pathogens.

\section{' $C a$. L. asiaticus' infection affects}

citrus response to exogenously applied $\mathrm{SA}$.

It has been reported that the NahG SA hydroxylase from P. putida can inactivate exogenously applied SA and prevents the activation of SAR in transgenic NahG Arabidopsis (Lawton et al. 1995). We hypothesized that ' $C a$. L. asiaticus' infection will affect citrus responses to exogenously applied SA, as the bacterium codes for an active SA hydroxylase. To test this hypothesis, ' $C a$. L. asiaticus'-infected and healthy plants of Valencia sweet orange were treated with SA $(1.0 \mathrm{mM})$ by foliar spray, and the levels of expression of $P R-1, P R-2$, and $P R-5$ genes in treated leaves were determined at different time points. The levels of expression of the $P R$ genes increased after SA application in both healthy and ' $\mathrm{Ca}$. L. asiaticus'-infected citrus plants. However, the expression levels of all three $P R$ genes were significantly lower in the ' $C a$. L. asiaticus'-infected plants as compared with healthy plants at the same indicated time points, i.e., 24, 48, and $72 \mathrm{~h}$ post-SA application (Fig. 6A). Similarly, the content of endogenous SA in ' $\mathrm{Ca}$. L. asiaticus'-infected leaf samples was significantly lower than that of the healthy samples at 24, 48 and $72 \mathrm{~h}$ after application of SA (Fig. 6B). The pattern of SA accumulation in the leaf samples correlated with the expression pattern of $P R$ genes following exogenously application of SA. We also tested the effect of BTH and INA on $P R$ gene expression between healthy and ' $C a$. L. asiaticus'-infected citrus. The expression levels of $P R-1, P R-2$, or $P R-5$ in the ' $C a$. L. asiaticus'-infected plants were similar to those in healthy plants at the same indicated time points, following BTH or INA application (Supplementary Fig. S6). These results suggest that ' $C a$. L. asiaticus' infection affects citrus response to exogenously applied SA.

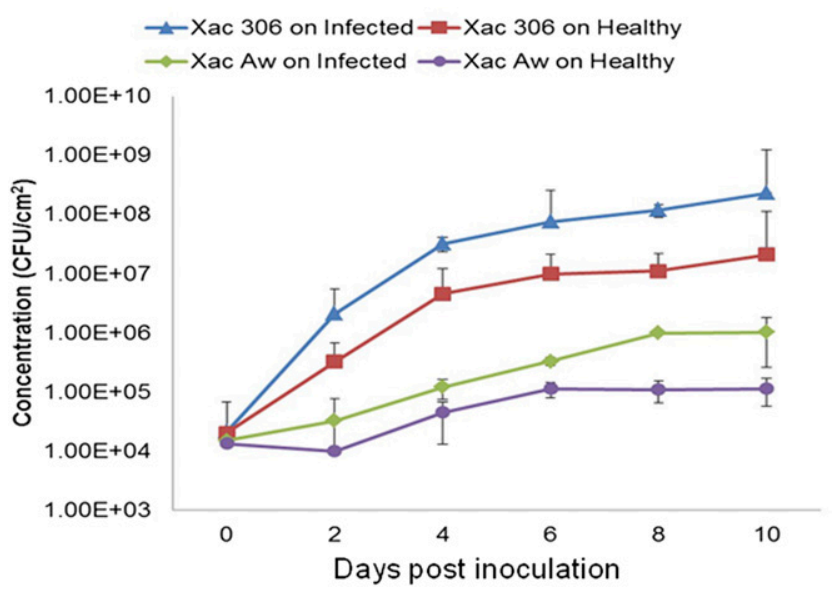

Fig. 5. Population dynamics of Xanthomonas citri $\mathrm{A} 306$ and X. citri $\mathrm{A}^{\mathrm{W}}$ in 'Candidatus Liberibacter asiaticus'-infected and healthy Duncan grapefruit. Bacterial cells were inoculated into grapefruit leaves at a concentration of $10^{6} \mathrm{CFU}$ per milliliter. Bacterial cells from the inoculated leaves were recovered at different time points, and the values represent the mean of four replicates. Means \pm standard error are plotted. Error bars indicate standard error of mean.
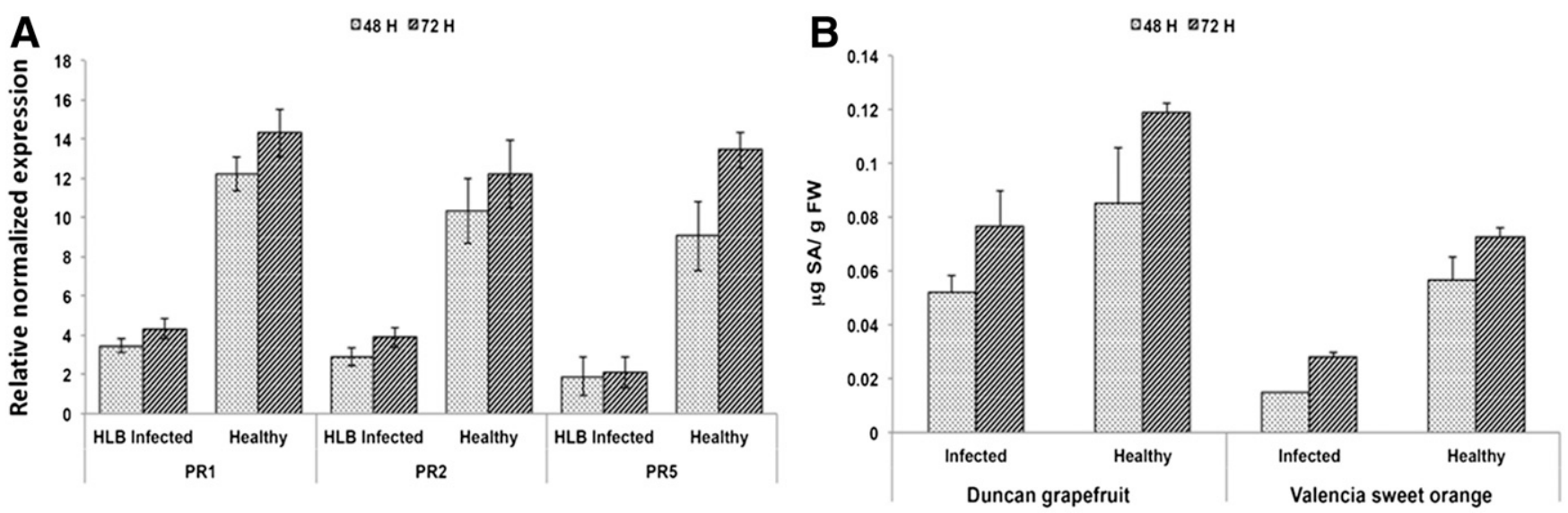

Fig. 4. Effects of 'Candidatus Liberibacter asiaticus' infection on pathogenesis-related (PR) gene expression and salicylic acid (SA) accumulation in citrus in response to subsequent Xanthomonas citri subsp. citri $\mathrm{A}^{\mathrm{W}}$ inoculation. A, Expression pattern of citrus $P R-1, P R-2$, and $P R-5$ genes following inoculation with X. citri $\mathrm{A}^{\mathrm{W}}$ in 'Ca. L. asiaticus'-infected and healthy leaves of Duncan grapefruit. The leaves were inoculated with $X$. citri $\mathrm{A}^{\mathrm{W}}\left(10^{5} \mathrm{CFU} / \mathrm{ml}\right) . \mathrm{Relative}$ transcript abundance of the $P R$ genes was calculated by calibrating the reverse transcription- quantitative polymerase chain reaction data to the healthy control prior to bacterial inoculation. B, High-pressure liquid chromatography-based measurement of free SA content (micrograms per gram of fresh weight [FW]) in 'Ca. L. asiaticus'-infected and healthy leaves of Duncan grapefruit and Valencia sweet orange following inoculation with $X$. citri $\mathrm{A}^{\mathrm{W}}\left(10^{5} \mathrm{CFU} / \mathrm{ml}\right)$. Three biological replicates were performed. Error bars indicate standard error of mean. 


\section{Effects of SA analogs}

\section{on the control of citrus HLB in the field.}

We reasoned that application of SA analogs would neutralize the effect of SA hydroxylase and thereby control HLB. To test this hypothesis, the SA analogs BTH and INA were applied to foliage of HLB-diseased Hamlin sweet orange $(C$. sinensis) trees during flushes for two seasons, with three or four applications in each season. As the experiment progressed, the HLB severity generally increased for all treatments over time (Fig. 7). This is consistent with the increase of ' $\mathrm{Ca}$. L. asiaticus' titers in all treatments evaluated in November 2015, April 2016, and October 2016 (Table 2). However, the treatments of BTH,
INA, and SA slowed down the progression of HLB disease severity and ' $C a$. L. asiaticus' titers compared with the nontreated control (Fig. 7; Table 2). Compared with the nontreated control, BTH $(1.0 \mathrm{mM})$, INA $(1.0 \mathrm{mM})$, and SA $(1.0 \mathrm{mM})$ reduced HLB disease severity by $22.7,23.8$, and $20.4 \%$, respectively, at the time of collecting data in October 2016 (Fig. 7; treatment $P<0.05$ ). Both BTH and INA seem more effective in suppressing the progression of HLB disease severity than SA (Fig. 7), although it is not statistically significant. One possible reason for this observation is that the exogenously applied SA level may be over the capacity of SA hydroxylase of ' $\mathrm{Ca}$. L. asiaticus' in the treated trees.
A

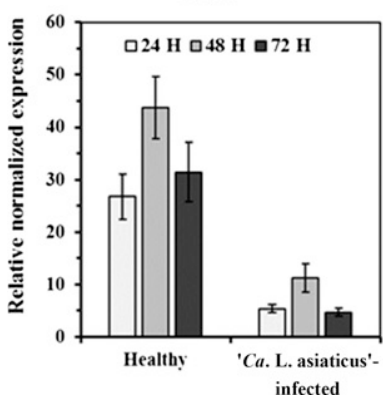

PR2

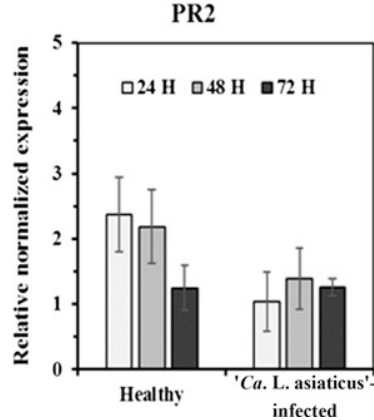

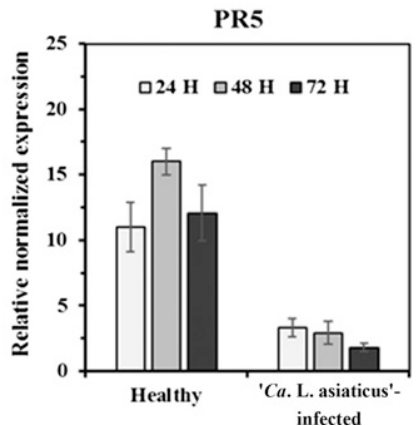

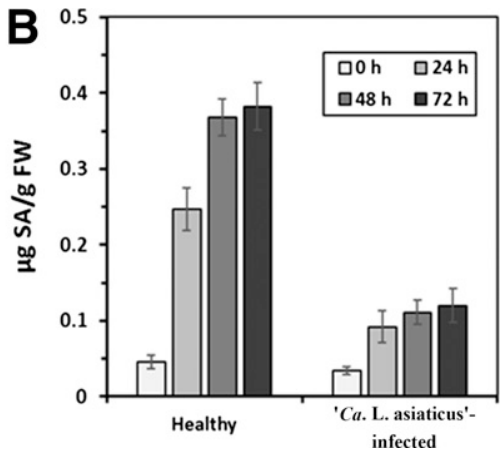

Fig. 6. Effects of 'Candidatus Liberibacter asiaticus' infection on pathogenesis-related (PR) gene expression and salicylic acid (SA) accumulation in citrus in response to exogenously applied SA. A, Expression pattern of citrus $P R-1, P R-2$, and $P R-5$ genes following treatment with SA in ' $C a$. L. asiaticus'-infected and healthy leaves of Valencia sweet orange. The leaves were sprayed with SA $(1.0 \mathrm{mM})$. Relative transcript abundance of the $P R$ genes was normalized against their expression levels prior to SA application. B, High-pressure liquid chromatography-based measurement of free SA content (micrograms per gram of fresh weight $[\mathrm{FW}])$ in ' $\mathrm{Ca}$. L. asiaticus'-infected and healthy leaves of Valencia sweet orange following treatment with SA. Four biological replicates were performed. Error bars indicate standard error of mean.
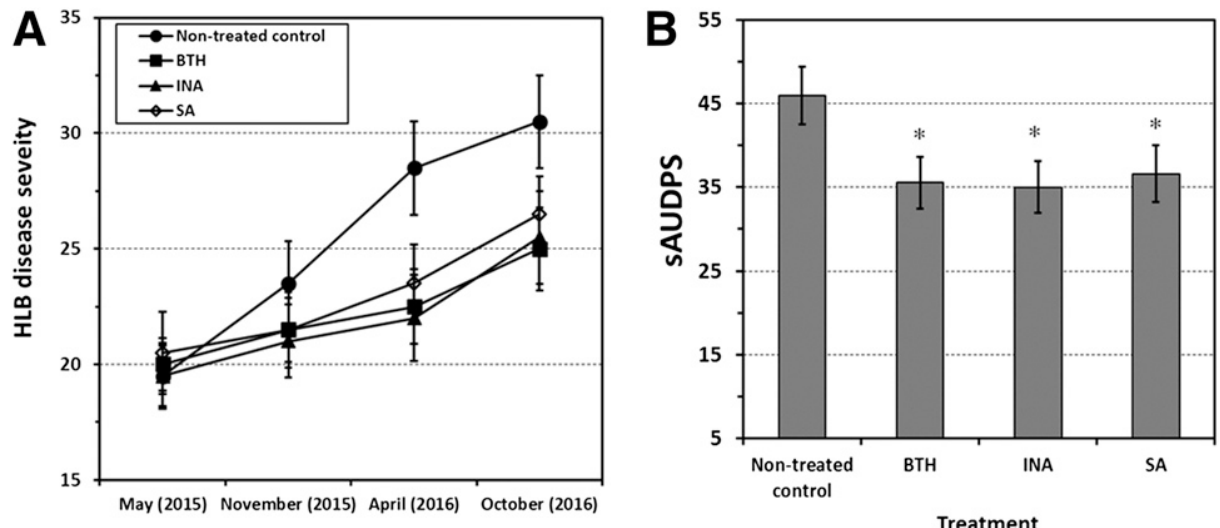

Fig. 7. Effect of salicylic acid (SA) analogs on control of Huanglongbing (HLB). A, HLB disease progression in the treated Hamlin sweet orange trees in the Citrus Research and Education Center main grove. Nontreated control: water. The average disease-severity scores were calculated from evaluations of the treated trees. Bars represent the standard error of the mean value. B, Disease severity of HLB expressed as the standardized area under the disease progress stairs (sAUDPS) in the experiment over time. Bars represent the standard error of the mean value. Asterisks indicate a significant difference $(P<0.05)$ between the treatment and nontreated control based on Student's $t$ test. BTH =2,1,3-benzothiadiazole and INA = 2,6-dichloroisonicotinic acid.

Table 2. 'Candidatus Liberibacter asiaticus' titers in leaf samples under different treatments in the field ${ }^{2}$

\begin{tabular}{lcccc}
\hline & \multicolumn{4}{c}{ 'Ca. L. asiaticus' population (cells per gram of plant tissue) } \\
\cline { 2 - 5 } Treatment & May 2015 & November 2015 & April 2016 & October 2016 \\
\hline Water & $(5.25 \pm 0.54) \times 10^{6} \mathrm{a}$ & $(1.47 \pm 0.21) \times 10^{7} \mathrm{a}$ & $(3.84 \pm 0.35) \times 10^{7} \mathrm{a}$ & $(4.68 \pm 0.36) \times 10^{7} \mathrm{a}$ \\
BTH $(1.0 \mathrm{mM})$ & $(5.07 \pm 0.63) \times 10^{6} \mathrm{a}$ & $(0.96 \pm 0.07) \times 10^{7} \mathrm{a}$ & $(1.66 \pm 0.22) \times 10^{7} \mathrm{~b}$ & $(2.28 \pm 0.34) \times 10^{7} \mathrm{~b}$ \\
INA $(1.0 \mathrm{mM})$ & $(4.84 \pm 0.65) \times 10^{6} \mathrm{a}$ & $(0.92 \pm 0.11) \times 10^{7} \mathrm{a}$ & $(1.75 \pm 0.25) \times 10^{7} \mathrm{~b}$ & $(2.37 \pm 0.28) \times 10^{7} \mathrm{~b}$ \\
SA $(1.0 \mathrm{mM})$ & $(5.72 \pm 0.47) \times 10^{6} \mathrm{a}$ & $(0.99 \pm 0.09) \times 10^{7} \mathrm{a}$ & $(1.92 \pm 0.27) \times 10^{7} \mathrm{~b}$ & $(2.86 \pm 0.39) \times 10^{7} \mathrm{~b}$ \\
\hline
\end{tabular}

${ }^{\mathrm{z}}$ Data shown are means and standard errors of three replicates. Values with different letters within each column in the same experiment indicate significant difference $(P<0.05$, Student's $t$ test $)$. BTH $=2,1,3$-benzothiadiazole, INA $=2$,6-dichloroisonicotinic acid, and SA $=$ salicylic acid. 


\section{DISCUSSION}

'Ca. L. asiaticus' has emerged as the most destructive pathogen on citrus worldwide (Bové 2006; Wang and Trivedi 2013). Genomics-based research has improved understanding of pathogenic mechanisms and plant responses during pathogen infection (Aritua et al. 2013; Mafra et al. 2013; Rawat et al. 2015). However, to date, the virulence mechanisms and molecular basis of the pathogen-plant interactions are still largely unknown, mainly due to the failure to culture the pathogens in axenic media. Identifying pathogen virulence factors and their functions will lead to detailed understanding of how infection is established and will hold promise for developing novel approaches to control the infection. Notably, all genome-sequenced pathogenic ' $\mathrm{Ca}$. Liberibacter' species encode a putative relatively conserved SA hydroxylase (Duan et al. 2009; Katoh et al. 2014; Lin et al. 2013; Wulff et al. 2014) (Fig. 2). We hypothesized that SA hydroxylase plays an important role in the pathogen-plant interactions by degrading SA triggered by pathogen infection and, consequently, suppressing plant defenses. The functional data presented here established the ' $\mathrm{Ca}$. L. asiaticus' SA hydroxylase SahA as a critical virulence factor for initial infection and long-term survival and persistence in citrus. Even though SahA has a similar function as the $P$. putida NahG, they share low identity (Fig. 2) and NahG does not contribute to virulence on the plant. In addition, ' $C a$. Liberibacter' species lack other components of the SA metabolism pathway. Therefore, we did not name it as NahG.

SA accumulation and downstream signaling events play a central role in plant defense against invading pathogens in many plant species (Fu and Dong 2013; Mishina and Zeier 2007; Park et al. 2007). Previous studies have shown that SAmediated immune responses are important components of both PTI and ETI and, also, essential for the triggering of SAR (An and Mou 2011; Vlot et al. 2009) and that inhibiting SA biosynthesis or blocking SA accumulation enhances plant susceptibility to pathogen (An and Mou 2011). Notably, SA has been shown to be synthesized in the chloroplast (Fragnière et al. 2011) and transported systemically via the phloem (Métraux et al. 1990; Molders et al. 1996). Given that the ' $C a$. L. asiaticus' SahA encodes a functional active SA-degrading enzyme both in vitro (Table 1) and in planta (Fig. 3), it is therefore highly likely that ' $\mathrm{Ca}$. L. asiaticus' evades SAmediated immune responses in phloem, using its SA hydroxylase activity during an early stage of infection, and builds up and maintains a significant titer in citrus associated with HLB disease progression over several years before the tree becomes dying.

Multiple lines of evidence lent support to the argument that ' $C a$. L. asiaticus' suppresses plant defenses by degrading SA. The purified SA hydroxylase of ' $\mathrm{Ca}$. L. asiaticus' was able to degrade SA and its derivatives with a relatively high enzymatic activity (Table 1). Transgenic tobacco plants expressing the $\operatorname{sah} A$ gene are unable to accumulate SA and activate the HR when challenged by the nonhost pathogen $X$. citri (Fig. 3 ). SA is transmitted in the phloem, in which ' $\mathrm{Ca}$. L. asiaticus' resides, and it has a low molecular weight of $138 \mathrm{Da}$, which allows it to easily traverse the membrane of ' $\mathrm{Ca}$. L. asiaticus' to be degraded by SA hydroxylase. The close relative of ' $\mathrm{Ca}$. L. asiaticus', Liberibacter crescens, containing a homolog of SahA with a $47 \%$ amino acid identity, is able to grow in the presence of SA (10 to $50 \mu \mathrm{M}$ ), probably by degrading SA (Supplementary Fig. S4), which supports the notion that ' $\mathrm{Ca}$. L. asiaticus' is able to degrade SA. Additionally, compared with healthy citrus, ' $C a$. L. asiaticus'-infected citrus has reduced SA accumulation and $P R$ gene expression in response to subsequent $X$. citri $\mathrm{A}^{\mathrm{W}}$ inoculation (Fig. 4). X. citri $\mathrm{A}^{\mathrm{W}}$ causes HR on grapefruit and is nonpathogenic on Valencia sweet orange (Egel et al. 1991; Rybak et al. 2009). SA accumulation and the expression of $P R$ genes have been suggested to play critical roles in the resistance of citrus varieties against X. citri infection (Shi et al. 2015; Wang and Liu 2012). The reduced SA level and $P R$ gene expression in HLBdiseased plants compared with healthy plants in response to $X$. citri $\mathrm{A}^{\mathrm{W}}$ infection suggests that ' $C a$. L. asiaticus' degrades SA using its SA hydroxylase. Furthermore, ' $\mathrm{Ca}$. L. asiaticus' infection affects citrus response to exogenously applied SA. Compared with healthy citrus, ' $\mathrm{Ca}$. L. asiaticus'-infected citrus has reduced endogenous SA accumulation and weaker $P R$ gene expression in response to exogenous SA (Fig. 6).

' $C a$. L. asiaticus' contains many potential PAMPs that might lead to activation of plant defenses and induction of SA synthesis (Duan et al. 2009). It has been shown that ' $C a$. L. asiaticus' contains a functional fla gene encoding a flagellin and hook-associated protein containing the conserved flg22 (Zou et al. 2012). The fla gene is able to partially complement the corresponding Sinorhizobium meliloti fla mutant. Transient expression in planta of Fla induces cell death and callose deposition in $N$. benthamiana and upregulation of $B A K 1$ and $S G T 1$, which are associated with plant innate immunity. Thus, it has been suggested that the ' $\mathrm{Ca}$. L. asiaticus' flagellin may act as a PAMP and trigger host plant resistance to ' $\mathrm{Ca}$. $\mathrm{L}$. asiaticus' (Duan et al. 2009; Zou et al. 2012). Additionally, ' $\mathrm{Ca}$. L. asiaticus' contains LPS and peptidoglycan. Components of bacterial LPS have been shown to act as a PAMP. For example, lipid $\mathrm{A}$ is sensed by the cognate pattern recognition receptor (PRR) TLR4-MD2 to activate immunity (Kawasaki et al. 2001). Different motifs contained in bacterial peptidoglycan are recognized by the intracellular PRRs Nod1 and Nod2 to activate the immune system (Girardin et al. 2003a and b). However, it is probable that ' $\mathrm{Ca}$. L. asiaticus' has evolved to reduce the elicitation of PTI. Reductive evolution has been suggested for ' $C a$. L. asiaticus' with its $1.23-\mathrm{Mb}$ genome size, and many PAMPs are absent in ' $C a$. L. asiaticus' (Duan et al. 2009). In addition, infection of plant phloem, an intracellular environment, by ' $C a$. L. asiaticus' via psyllids avoids certain preformed plant defenses that ' $\mathrm{Ca}$. L. asiaticus' might otherwise encounter and it evades eliciting PTI, whose receptors are normally localized on the outer membrane (Greeff et al. 2012; Monaghan and Zipfel 2012). SA induction in citrus in response to ' $\mathrm{Ca}$. L. asiaticus' infection has been reported previously ( $\mathrm{Lu}$ et al. 2013). Increased content of volatile MeSA, which is released into the air and escapes degradation by ' $\mathrm{Ca}$. L. asiaticus' SA hydroxylase, has been observed from ' $\mathrm{Ca}$. L. asiaticus'infected trees compared with healthy controls (Mann et al. 2012). Overall, ' $C a$. L. asiaticus' is able to induce weak SA production, which is further complicated by ' $\mathrm{Ca}$. L. asiaticus' SA hydroxylase.

' $C a$. L. asiaticus' infection of citrus increases its susceptibility to $X$. citri. As shown in Figure 5, compared with healthy plants, ' $C a$. L. asiaticus'-infected grapefruit is more susceptible to $X$. citri $\mathrm{A}^{\mathrm{W}}$ and $X$. citri A inoculation. This is not surprising, because compatible pathogens are not usually associated with the induction of SAR (Fu and Dong 2013; Lawton et al. 1995; Ryals et al. 1995). It has been reported that virulent strains of the bacterial phytopathogen Pseudomonas syringae induce systemic susceptibility to secondary $P$. syringae infection in the host plant Arabidopsis thaliana (Cui et al. 2005). This systemic induced susceptibility is caused by the production of coronatine, a pathogen-derived functional and structural mimic of the phytohormone jasmonic acid (JA) and the mutually antagonistic interaction between the SA and JA signaling pathways (Cui et al. 2005). In addition, virus-induced 
susceptibility to bacterial superinfection has been reported (Navarini et al. 2006; Schliehe et al. 2015). It has been suggested that the innate antiviral immune response reduces the antibacterial granulocyte defense (Navarini et al. 2006). The increased susceptibility of ' $C a$. L. asiaticus'-infected citrus to $X$. citri infection might result from the degradation of SA by the ' $C a$. L. asiaticus' SA hydroxylase. SA is critical for the SAR to subsequent infection by the original pathogen or by a variety of other pathogens (Fu and Dong 2013; Lawton et al. 1995). The fact that ' $\mathrm{Ca}$. L. asiaticus' increases susceptibility to $X$. citri further complicates the issues in citrus-producing areas. $X$. citri infects most commercially grown citrus varieties, including sweet orange, grapefruit, and lemon [C. limon (L.) Burm. f.]. For the top three citrus producers, Brazil, China, and the United States, both HLB and citrus canker are present, which warrants an integrated pest management approach for both citrus HLB and canker diseases.

Experimental evidence presented here confirms that the SA hydroxylase is an important virulence factor critical for ' $\mathrm{Ca}$. $\mathrm{L}$. asiaticus' establishing infection and long-term persistent in citrus by degrading SA and suppressing host defenses. To neutralize the effect of SA hydroxylase, we may either inhibit SA hydroxylase or externally apply SA and its derivatives. Foliar application of BTH and INA showed positive control effects against HLB by slowing down the increase of ' $\mathrm{Ca}$. L. asiaticus' titers (Table 2) and disease severity compared with the non-treated control (Fig. 7). Application of exogenous SA and its functional analogs, such as INA and BTH, induces the expression of $P R$ genes and plant resistance against bacterial, viral, oomycete, and fungal pathogens (Görlach et al. 1996; Hukkanen et al. 2007; Wang and Liu 2012). The results provided here and our previous results ( $\mathrm{Li}$ et al. 2016) suggest that application of SA derivatives has positive HLB control effects, even though the effect is limited. We expect the control effect could be optimized by improving the application method or combining with SA hydroxylase inhibitors. SA hydroxylase seems to be an ideal target for small molecule inhibitor development because no human homolog is present and it is not essential for bacterial growth; hence, the possibility of resistance development is minimized.

\section{MATERIALS AND METHODS}

\section{Bacterial strains and growth conditions.}

The bacterial strains and plasmids used in this study are listed in SupplementaryTable S1. E. coli and A. tumefaciens strains were grown in Luria-Bertani (LB) medium at 37 and $28^{\circ} \mathrm{C}$, respectively. $X$. citri A306 and $\mathrm{A}^{\mathrm{W}} 12879$ strains were maintained on nutrient agar (NA) or nutrient broth $(\mathrm{NB})$ medium at $28^{\circ} \mathrm{C}$, with or without shaking. Antibiotics were used as needed at the following concentrations $(\mu \mathrm{g} / \mathrm{ml})$ : ampicillin, 100; kanamycin, 50; rifamycin, 50; and gentamycin, 5.

\section{RNA extraction and expression of $\operatorname{sah} A$ in infected citrus and psyllid by RT-qPCR.}

Psyllids were maintained on ' $C a$. L. asiaticus'-infected Valencia sweet orange in a secured greenhouse with a temperature of $24 \pm 2{ }^{\circ} \mathrm{C}$ and a relative humidity of $50 \% \pm 5 \%$. Psyllids ( $n=20$ to 25 ) were pooled and were ground in liquid nitrogen prior to RNA isolation. RNA extraction from ' $\mathrm{Ca}$. L. asiaticus'-infected citrus and psyllids and subsequent RTqPCR was performed using an Applied Biosystems 7500 Fast real-time PCR system (Foster City, CA, U.S.A.), as described by Yan et al. (2013). Two technical replicates were performed for eight biological replicates for RNA extracted from ' $C a$. L. asiaticus'-infected citrus and psyllid, along with no-template controls and no-reverse transcription controls.
Relative expression levels of $s a h A$, which were normalized using the reference gene $g y r B$, were calculated with the $\Delta \Delta \mathrm{Ct}$ method (Livak and Schmittgen 2001). Statistical analysis of all data were conducted by Student's $t$ test (SAS v9.2).

\section{Expression and purification of the SahA SA hydroxylase.}

The full-length open reading frame of the sahA gene of ' $C a$. L. asiaticus' was amplified by PCR with genomic DNA extracted from the midribs of symptomatic leaves of HLBdiseased Valencia sweet orange and gene-specific primers (Supplementary Table S2). The purified DNA fragment was cloned into the plasmid pHMAL-c5x that was modified from the vector pMAL-c5x (New England Biolabs, Ipswich, MA, U.S.A.) with addition of histidine tag (Zhou et al. 2016). Overexpressed MBP-SahA fusion protein in E. coli BL21 Star (DE3) pLysS (Invitrogen, Carlsbad, CA, U.S.A.) was purified according to the instructions of the QIAexpressionist (Qiagen), with modifications. Briefly, a 500-ml culture of E. coli cells containing the expression vector were grown at $37^{\circ} \mathrm{C}$ in $\mathrm{LB}$ medium to an optical density at $600 \mathrm{~nm}$ of 0.8 and were then incubated with $0.1 \mathrm{mM}$ isopropyl $\beta$-D-1-thiogalactopyranoside for $2.5 \mathrm{~h}$. Cells were sonicated in purification buffer $(50 \mathrm{mM}$ Tris-HCl, pH 8.0, $200 \mathrm{mM} \mathrm{NaCl}, 1 \mathrm{mM}$ EDTA, $1 \mathrm{mM}$ dithiothreitol) at $4^{\circ} \mathrm{C}$. Crude extract from $E$. coli cells was incubated with Ni-NTA agarose for $30 \mathrm{~min}$. The agarose beads were then washed with 10 volumes of purification buffer with addition of $20 \mathrm{mM}$ imidazole. The protein was eluted in purification buffer containing $300 \mathrm{mM}$ imidazole. The purified protein was evaluated using sodium dodecyl sulfate-polyacrylamide gel electrophoresis. MBP was cleaved from the fusion protein with the protease Factor Xa (New England Biolabs). The concentration of purified SahA protein was measured with a DC protein assay kit (Bio-Rad, Hercules, CA, U.S.A.).

\section{Testing for SA hydroxylase activity.}

The enzymatic activity of SA hydroxylase against SA and SA analogs, i.e., sodium salicylate, 3-methylsalicylate, 4methylsalicylate, 3-chlorosalicylate, and 5-chlorosalicylate, as well as the SAR inducers BTH and INA was tested as described by White-Stevens and Kamin (1972a and b). SA hydroxylase activities were measured by following NADHoxidation activity as a decrease in absorbance at $340 \mathrm{~nm}$ in a certain time period (5 to $10 \mathrm{~min}$ ) compared with the blank control (buffer only, without the purified protein). The BSA protein was used as a negative control in SA hydroxylase activity assays. One unit of enzyme converts $1.0 \mu$ mole of salicylate and $\beta$-NADH to catechol and $\beta$-NAD per minute, at $\mathrm{pH} 7.6$, at $30^{\circ} \mathrm{C}$. The enzymatic activity was calculated as mmol NADH per minute per milligram of protein.

\section{Plasmid construction, plant transformation, and HR assays.}

The full-length sahA gene was amplified by PCR, using specific primers from genomic DNA extracted as described above. The PCR product was verified by sequencing, and then, was cloned into the binary vector pERGFP-1380N, under the control of the Cauliflower mosaic virus $35 \mathrm{~S}$ promoter. The construct was confirmed by sequencing and was transferred to A. tumefaciens LBA4404 for tobacco (N. tabacum cv. Petite Havana SR1) transformation, using the leaf-disk transformation method (Gallois and Marinho 1995). T0 seeds were selected for T1 plants on Murashige-Skoog (Sigma-Aldrich, St. Louis) plates supplemented with $200 \mu \mathrm{g}$ of naphthalene acetic acid per milliliter and $3.0 \mathrm{mg}$ 6-BA per liter and containing kanamycin $(100 \mu \mathrm{g} / \mathrm{ml})$ and cephotaxime $(500 \mu \mathrm{g} / \mathrm{ml})$. T1 transgenic plants were maintained in a greenhouse and were collected for seeds, which were further selected for homozygous T2 plants. 
Individual transformed plants were tested for inserts by PCR, and selected transgenic plants were verified by sequencing. The expression levels of the transgene sahA in selected transgenic plants were analyzed by RT-qPCR using gene specific primers and were calculated with the $\Delta \Delta \mathrm{Ct}$ method as described above, with the tobacco actin gene as an endogenous reference control. The expression of SahA protein was confirmed by Western blotting. The hemagglutinin (HA) tag-specific antibody (antiHA) (Invitrogen) was used to detect the SahA-3 $\times$ HA fused protein expressed in transgenic plants. The data of RT-qPCR and Western blotting analysis were presented in Supplementary Figure S5. Four-week-old T2 transgenic plants with high expression levels of the sahA gene were used for HR assays. The induction of HR by $X$. citri cells was performed as described previously (Zhou et al. 2016). SA content in the $X$. citriinoculated leaf tissues was determined with high-pressure liquid chromatography (HPLC) as described by Verberne et al. (2002).

\section{Testing the effects of ' $\mathrm{Ca}$. $\mathrm{L}$. asiaticus' infection on $\mathrm{SA}$ accumulation and $P R$ gene expression in citrus in response to subsequent $X$. citri $\mathrm{A}^{\mathrm{W}}$ inoculation.}

Nine-month-old healthy and ' $C a$. L. asiaticus'-infected seedlings of Valencia sweet orange and Duncan grapefruit were used for inoculation with $X$. citri $\mathrm{A}^{\mathrm{W}}$. For ' $C a$. L. asiaticus' infection, plants were previously graft-inoculated and were kept in a secured greenhouse with a temperature ranging from 26 to $32^{\circ} \mathrm{C}$. ' $\mathrm{Ca}$. L. asiaticus' infection was verified as described previously (Tatineni et al. 2008).

The strain $X$. citri $\mathrm{A}^{\mathrm{W}} 12879$ used in this assay was grown, with shaking at $28^{\circ} \mathrm{C}$, overnight in $\mathrm{NB}$ and was suspended in sterile tap water, and the concentration was adjusted to $10^{5}$ $\mathrm{CFU} / \mathrm{ml}$. For the inoculation assays, whole leaves (three plants per treatment, six leaves per plant) were inoculated by infiltration of the abaxial leaf surface, using a needleless syringe as described previously (Guo et al. 2010). Leaf samples were collected at 0,48 , or $72 \mathrm{~h}$ postinoculation and were ground in liquid nitrogen for analyses of SA content and $P R$ gene expression. Free $\mathrm{SA}$ in the $X$. citri $\mathrm{A}^{\mathrm{W}}$-inoculated leaf tissues at the indicated time points was measured with HPLC as described by Verberne et al. (2002). Three biological replicates were used. The assays were repeated two times independently with similar results, and the results are the mean of two independent experiments.

To determine $P R$ gene expression, total RNA was extracted using the RNeasy plant mini kit (Qiagen). Contaminating genomic DNA was removed by RNA treatment with a TurboDNA free kit (Ambion, Austin, TX, U.S.A.), and the RNA was eluted in $30 \mu \mathrm{l}$ of water. RNA quantification was performed using a NanoDrop ND-1000 spectrophotometer (Nanodrop Technologies, Wilmington, DE, U.S.A.), and it was stored at $-80^{\circ} \mathrm{C}$. RT-qPCR assays were conducted to determine the expression of three $P R$ genes ( $P R-1, P R-2$, and $P R-5)$, using an Applied Biosystems 7500 Fast real-time PCR system, with the QuantiTect SYBR green RT-PCR kit (Qiagen). The PCR conditions were $30 \mathrm{~min}$ of reverse transcription at $50^{\circ} \mathrm{C}$, followed by $15 \mathrm{~min}$ of predenaturation at $95^{\circ} \mathrm{C}$ and 40 cycles of $15 \mathrm{~s}$ of denaturation at $94^{\circ} \mathrm{C}, 30 \mathrm{~s}$ of annealing at $55^{\circ} \mathrm{C}$, and $30 \mathrm{~s}$ of extension at $72^{\circ} \mathrm{C}$. The housekeeping gene encoding glyceraldehyde-3-phosphate dehydrogenase-C (GAPDH-C) was used as an endogenous control. Melting curve analysis was conducted to verify the specificity of the RT-qPCR products. The products were run on a $2 \%$ agarose gel to confirm the presence of only a single band. Two technical replicates and three biological replicates were used for each gene. The relative fold change in target gene expression was calculated using the formula $2^{\Delta \Delta C t}$ (Livak and Schmittgen
2001). Statistical analyses of all data were conducted by Student's $t$ test (SAS v9.2). The in planta assays were repeated two times, independently, with similar results, and the results are the mean of two independent experiments.

\section{Population of $X$. citri A306 and X. citri $\mathrm{A}^{\mathrm{W}} 12879$ in ' $\mathrm{Ca}$. L. asiaticus'-infected and healthy leaves of Duncan grapefruit.}

Strains $X$. citri $\mathrm{A} 306$ and $X$. citri $\mathrm{A}^{\mathrm{W}} 12879$ were grown, with shaking, at $28^{\circ} \mathrm{C}$, overnight in NB and were suspended in sterile tap water, and the concentration was adjusted to $10^{6}$ $\mathrm{CFU} / \mathrm{ml}$. Inoculation assays using ' $\mathrm{Ca}$. L. asiaticus'-infected and healthy leaves of Duncan grapefruit were performed using the infiltration method described above. Inoculation assays were conducted in a quarantined greenhouse facility at the Citrus Research and Education Center (CREC), Lake Alfred, FL, U.S.A. For the population dynamics study, leaf disks from inoculated leaves were excised at different time intervals with a cork borer (leaf area, $1 \mathrm{~cm}^{2}$ ) and werer then ground in $1 \mathrm{ml}$ of sterile tap water. The samples were serially diluted and were plated on NA plates and colonies were counted. The in planta growth assays were repeated three times, independently, with four replicates each time.

\section{Testing the effect of ' $\mathrm{Ca}$. L. asiaticus' infection on citrus response to exogenously applied SA.}

Two-year-old healthy and ' $\mathrm{Ca}$. L. asiaticus'-infected seedlings of Valencia sweet orange were spray-treated with SA $(1.0 \mathrm{mM})$, BTH $(1.0 \mathrm{mM})$, or INA $(1.0 \mathrm{mM})$, using a hand-held sprayer until runoff. Leaf samples were collected at 0 (pretreatment), 24, 48, 72, and $96 \mathrm{~h}$ posttreatment. For analysis of $P R$ gene expression, the leaf samples were immediately frozen in liquid nitrogen and were stored at $-80^{\circ} \mathrm{C}$ until processed, as described above. For SA content assays, leaf samples were washed in distilled water with sonication for $30 \mathrm{~min}$ and were then subjected to SA extraction, as described above. Four biological replicates were used and the assays were repeated two times independently.

\section{Assessment of the control effect of SA analogs on HLB.}

To test the control effect of SA analogs on HLB, BTH $(2.0 \mathrm{mM})$, INA $(2.0 \mathrm{mM})$, and SA $(2.0 \mathrm{mM})$ were used to treat HLB-diseased Hamlin sweet orange [C. sinensis (L.) Osbeck] on Swingle citrumelo [C. paradise Macf. 'Duncan' grapefruit $\times$ Poncirus trifoliata (L.) Raf.] rootstock planted in the CREC main grove. Water was used as a nontreated control. Each treatment consisted of eight replicate trees. Foliar applications were made every three or four months when flush was present, starting with the summer flush in June 2015. All trees selected for the experiment were chosen based on the presence of HLB symptoms and were confirmed to be HLB positive via qPCR assays (Trivedi et al. 2009). An attempt was made to select trees in the same stage of HLB symptom expression, i.e., initial HLB disease severity of 18 to 22 (Gottwald et al. 2007). All trees within the trial area were maintained at conventional management standards.

Disease severity and the ' $C a$. L. asiaticus' bacterial titers in treated trees were evaluated right before the treatment application and every six months after initial application. Disease-severity evaluations were performed using the method described by Gottwald et al. (2007). The disease-severity data from individual evaluations were also combined into a single value that was expressed as the area under the disease progress stairs (AUDPS) and its standardized AUDPS form, according to the method developed by Simko and Piepho (2012). The ' $\mathrm{Ca}$. L. asiaticus' bacterial titer in leaf samples was determined by qPCR assays, as described previously (Li et al. 2016). 


\section{ACKNOWLEDGMENTS}

We sincerely thank V. Kolbasov and D. Wilhite (University of Florida) for assistance in field tests. This study was supported by the Citrus Research and Development Foundation and United States Department of AgricultureSpecialty Block Grant 92137 to N. Wang.

\section{LITERATURE CITED}

Albrecht, U., and Bowman, K. D. 2012. Transcriptional response of susceptible and tolerant citrus to infection with Candidatus Liberibacter asiaticus. Plant Sci. 185-186:118-130.

Alvarez, S., Rohrig, E., Solís, D., and Thomas, M. H. 2016. Citrus greening disease (Huanglongbing) in Florida: Economic impact, management and the potential for biological control. Agric. Res. 5:109-118.

Ambrose, K. V., Tian, Z., Wang, Y., Smith, J., Zylstra, G., Huang, B., and Belanger, F. C. 2015. Functional characterization of salicylate hydroxylase from the fungal endophyte Epichloë festucae. Sci. Rep. 5:10939.

An, C., and Mou, Z. 2011. Salicylic acid and its function in plant immunity. J. Integr. Plant Biol. 53:412-428.

Aritua, V., Achor, D., Gmitter, F. G., Albrigo, G., and Wang, N. 2013 Transcriptional and microscopic analyses of citrus stem and root responses to Candidatus Liberibacter asiaticus infection. PLoS One 8:e73742.

Bosch, R., Moore, E. R. B., García-Valdés, E., and Pieper, D. H. 1999. $\mathrm{NahW}$, a novel, inducible salicylate hydroxylase involved in mineralization of naphthalene by Pseudomonas stutzeri AN10. J. Bacteriol. 181: 2315-2322.

Bové, J. M. 2006. Huanglongbing: A destructive, newly emerging, centuryold disease of citrus. J. Plant Pathol. 88:7-37.

Chen, Z., Zheng, Z., Huang, J., Lai, Z., and Fan, B. 2009. Biosynthesis of salicylic acid in plants. Plant Signal. Behav. 4:493-496.

Clarke, S. M., Mur, L. A., Wood, J. E., and Scott, I. M. 2004. Salicylic acid dependent signaling promotes basal thermotolerance but is not essential for acquired thermotolerance in Arabidopsis thaliana. Plant $\mathrm{J}$. 38:432-447.

Cui, J., Bahrami, A. K., Pringle, E. G., Hernandez-Guzman, G., Bender, C. L., Pierce, N. E., and Ausubel, F. M. 2005. Pseudomonas syringae manipulates systemic plant defenses against pathogens and herbivores. Proc. Natl. Acad. Sci. U.S.A. 102:1791-1796.

Duan, Y., Zhou, L., Hall, D. G., Li, W., Doddapaneni, H., Lin, H., Liu, L., Vahling, C. M., Gabriel, D. W., Williams, K. P., Dickerman, A., Sun, Y., and Gottwald, T. 2009. Complete genome sequence of citrus Huanglongbing bacterium, 'Candidatus Liberibacter asiaticus' obtained through metagenomics. Mol. Plant-Microbe Interact 22:1011-1020.

Egel, D. S., Graham, J. H., and Stall, R. E. 1991. Genomic relatedness of Xanthomonas campestris strains causing diseases of citrus. Appl Environ. Microbiol. 57:2724-2730.

Eppink, M. H. M., Schreuder, H. A., and Van Berkel, W. J. H. 1997. Identification of a novel conserved sequence motif in flavoprotein hydroxylases with a putative dual function in FAD/NAD $(\mathrm{P}) \mathrm{H}$ binding. Protein Sci. 6:2454-2458.

Fragnière, C., Serrano, M., Abou-Mansour, E., Métraux, J. P., and L'Haridon, F. 2011. Salicylic acid and its location in response to biotic and abiotic stress. FEBS Lett. 585:1847-1852.

Fu, Z. Q., and Dong, X. 2013. Systemic acquired resistance: Turning local infection into global defense. Annu. Rev. Plant Biol. 64:839-863.

Gallois, P., and Marinho, P. 1995. Leaf disk transformation using Agrobacterium tumefaciens-expression of heterologous genes in tobacco. Methods Mol. Biol. 49:39-48.

Girardin, S. E., Boneca, I. G., Carneiro, L. A., Antignac, A., Jéhanno, M., Viala, J., Tedin, K., Taha, M. K., Labigne, A., Zähringer, U., Coyle, A. J., DiStefano, P. S., Bertin, J., Sansonetti, P. J., and Philpott, D. J. 2003a Nod1 detects a unique muropeptide from gram-negative bacterial peptidoglycan. Science 300:1584-1587.

Girardin, S. E., Boneca, I. G., Viala, J., Chamaillard, M., Labigne, A., Thomas, G., Philpott, D. J., and Sansonetti, P. J. 2003b. Nod2 is a general sensor of peptidoglycan through muramyl dipeptide (MDP) detection. J. Biol. Chem. 278:8869-8872.

Görlach, J., Volrath, S., Knauf-Beiter, G., Hengy, G., Beckhove, U., Kogel, K. H., Oostendorp, M., Staub, T., Ward, E., Kessmann, H., and Ryals, J. 1996. Benzothiadiazole, a novel class of inducers of systemic acquired resistance, activates gene expression and disease resistance in wheat. Plant Cell 8:629-643.

Gottwald, T., da Graça, J., and Renato, B. 2007. Citrus Huanglongbing: The pathogen and its impact. Plant Health Prog. Published online. doi: 10.1094/PHP-2007-0906-01-RV

Gottwald, T. R. 2010. Current epidemiological understanding of citrus Huanglongbing. Annu. Rev. Phytopathol. 48:119-139.
Greeff, C., Roux, M., Mundy, J., and Petersen, M. 2012. Receptor-like kinase complexes in plant innate immunity. Front. Plant Sci. 3:209.

Guo, Y., Sagaram, U. S., Kim, J. S., and Wang, N. 2010. Requirement of the galU gene for polysaccharide production by and pathogenicity and growth in planta of Xanthomonas citri subsp. citri. Appl. Environ Microbiol. 76:2234-2242.

Halbert, S. E. 2005. The discovery of Huanglongbing in Florida. Page H-3 in: Proceedings of the 2nd International Citrus Canker and Huanglongbing Research Workshop. Florida Citrus Mutual, Orlando, FL, U.S.A.

Hao, G., Boyle, M., Zhou, L., and Duan, Y. 2013. The intracellular citrus Huanglongbing bacterium, 'Candidatus Liberibacter asiaticus' encodes two novel autotransporters. PLoS One 8:e68921.

Hukkanen, A. T., Kokko, H. I., Buchala, A. J., McDougall, G. J., Stewart, D., Kärenlampi, S. O., and Karjalainen, R. O. 2007. Benzothiadiazole induces the accumulation of phenolics and improves resistance to powdery mildew in strawberries. J. Agric. Food Chem. 55:1862-1870.

Jain, M., Fleites, L. A., and Gabriel, D. W. 2015. Prophage-encoded peroxidase in 'Candidatus Liberibacter asiaticus' is a secreted effector that suppresses plant defenses. Mol. Plant-Microbe Interact 28:1330-1337.

Jones, J. D., and Dangl, J. L. 2006. The plant immune system. Nature 444: 323-329.

Katoh, H., Miyata, S., Inoue, H., and Iwanami, T. 2014. Unique features of a Japanese 'Candidatus Liberibacter asiaticus' strain revealed by whole genome sequencing. PLoS One 9:e106109.

Kawasaki, K., Akashi, S., Shimazu, R., Yoshida, T., Miyake, K., and Nishijima, M. 2001. Involvement of TLR4/MD-2 complex in speciesspecific lipopolysaccharide-mimetic signal transduction by Taxol. J. Endotoxin Res. 7:232-236.

Kim, J.-S., Sagaram, U. S., Burns, J. K., Li, J.-L., and Wang, N. 2009. Response of sweet orange (Citrus sinensis) to 'Candidatus Liberibacter asiaticus' infection: Microscopy and microarray analyses. Phytopathology 99:50-57.

Lawton, K., Weymann, K., Friedrich, L., Vernooij, B., Uknes, S., and Ryals, J. 1995. Systemic acquired resistance in Arabidopsis requires salicylic acid but not ethylene. Mol. Plant-Microbe Interact 8:863-870.

Lee, S., Kim, S. G., and Park, C. M. 2010. Salicylic acid promotes seed germination under high salinity by modulating antioxidant activity in Arabidopsis. New Phytol. 188:626-637.

Li, J., Trivedi, P., and Wang, N. 2016. Field evaluation of plant defense inducers for the control of citrus Huanglongbing. Phytopathology 106:37-46.

Liao, H. L., and Burns, J. K. 2012. Gene expression in Citrus sinensis fruit tissues harvested from Huanglongbing-infected trees: Comparison with girdled fruit. J. Exp. Bot. 63:3307-3319.

Lin, H., and Gudmestad, N. C. 2013. Aspects of pathogen genomics, diversity, epidemiology, vector dynamics, and disease management for a newly emerged disease of potato: Zebra chip. Phytopathology 103:524-537.

Lin, H., Han, C. S., Liu, B., Lou, B., Bai, X., Deng, C., Civerolo, E. L., and Gupta, G. 2013. Complete genome sequence of a Chinese strain of "Candidatus Liberibacter asiaticus.". Genome Announc. 1:e00184-13.

Livak, K. J., and Schmittgen, T. D. 2001. Analysis of relative gene expression data using real-time quantitative PCR and the $2^{-\Delta \Delta C T}$ method. Methods 25:402-408.

Lowe-Power, T. M., Jacobs, J. M., Ailloud, F., Fochs, B., Prior, P., and Allen, C. 2016. Degradation of the plant defense signal salicylic acid protects Ralstonia solanacearum from toxicity and enhances virulence on tobacco. MBio 7:e00656-16.

Lu, H., Zhang, C., Albrecht, U., Shimizu, R., Wang, G., and Bowman, K. D. 2013. Overexpression of a citrus NDR1 ortholog increases disease resistance in Arabidopsis. Front. Plant Sci. 4:157.

Mafra, V., Martins, P. K., Francisco, C. S., Ribeiro-Alves, M., Freitas-Astúa, J., and Machado, M. A. 2013. Candidatus Liberibacter americanus induces significant reprogramming of the transcriptome of the susceptible citrus genotype. BMC Genomics 14:247.

Mann, R. S., Ali, J. G., Hermann, S. L., Tiwari, S., Pelz-Stelinski, K. S., Alborn, H. T., and Stelinski, L. L. 2012. Induced release of a plantdefense volatile 'deceptively' attracts insect vectors to plants infected with a bacterial pathogen. PLoS Pathog. 8:e1002610.

Métraux, J. P., Signer, H., Ryals, J., Ward, E., Wyss-Benz, M., Gaudin, J., Raschdorf, K., Schmid, E., Blum, W., and Inverardi, B. 1990. Increase in salicylic acid at the onset of systemic acquired resistance in cucumber. Science 250:1004-1006.

Mishina, T. E., and Zeier, J. 2007. Pathogen-associated molecular pattern recognition rather than development of tissue necrosis contributes to bacterial induction of systemic acquired resistance in Arabidopsis. Plant J. 50:500-513.

Molders, W., Buchala, A., and Metraux, J. P. 1996. Transport of salicylic acid in tobacco necrosis virus-infected cucumber plants. Plant Physiol 112:787-792 
Molinari, S., Fanelli, E., and Leonetti, P. 2014. Expression of tomato salicylic acid (SA)-responsive pathogenesis-related genes in $\mathrm{Mi}$-1mediated and SA-induced resistance to root-knot nematodes. Mol. Plant Pathol. 15:255-264.

Monaghan, J., and Zipfel, C. 2012. Plant pattern recognition receptor complexes at the plasma membrane. Curr. Opin. Plant Biol. 15:349-357.

Mori, I. C., Pinontoan, R., Kawano, T., and Muto, S. 2001. Involvement of superoxide generation in salicylic acid-induced stomatal closure in Vicia faba. Plant Cell Physiol. 42:1383-1388.

Morris, K., MacKerness, S. A. H., Page, T., John, C. F., Murphy, A. M., Carr, J. P., and Buchanan-Wollaston, V. 2000. Salicylic acid has a role in regulating gene expression during leaf senescence. Plant J. 23:677-685.

Navarini, A. A., Recher, M., Lang, K. S., Georgiev, P., Meury, S., Bergthaler, A., Flatz, L., Bille, J., Landmann, R., Odermatt, B., Hengartner, H., and Zinkernagel, R. M. 2006. Increased susceptibility to bacterial superinfection as a consequence of innate antiviral responses. Proc. Natl. Acad. Sci. U.S.A. 103:15535-15539.

Nwugo, C. C., Lin, H., Duan, Y., and Civerolo, E. L. 2013. The effect of 'Candidatus Liberibacter asiaticus' infection on the proteomic profiles and nutritional status of pre-symptomatic and symptomatic grapefruit (Citrus paradisi) plants. BMC Plant Biol. 13:59.

Pagliai, F. A., Gardner, C. L., Bojilova, L., Sarnegrim, A., Tamayo, C., Potts, A. H., Teplitski, M., Folimonova, S. Y., Gonzalez, C. F., and Lorca, G. L. 2014. The transcriptional activator LdtR from 'Candidatus Liberibacter asiaticus' mediates osmotic stress tolerance. PLoS Pathog. 10:e1004101.

Park, S. W., Kaimoyo, E., Kumar, D., Mosher, S., and Klessig, D. F. 2007. Methyl salicylate is a critical mobile signal for plant systemic acquired resistance. Science 318:113-116.

Pitino, M., Armstrong, C. M., Cano, L. M., and Duan, Y. 2016. Transient expression of Candidatus Liberibacter asiaticus effector induces cell death in Nicotiana benthamiana. Front. Plant Sci. 7:982.

Rabe, F., Ajami-Rashidi, Z., Doehlemann, G., Kahmann, R., and Djamei, A. 2013. Degradation of the plant defence hormone salicylic acid by the biotrophic fungus Ustilago maydis. Mol. Microbiol. 89:179-188.

Rawat, N., Kiran, S. P., Du, D., Gmitter, F. G., Jr., and Deng, Z. 2015. Comprehensive meta-analysis, co-expression, and miRNA nested network analysis identifies gene candidates in citrus against Huanglongbing disease. BMC Plant Biol. 15:184.

Ryals, J., Lawton, K. A., Delaney, T. P., Friedrich, L., Kessmann, H., Neuenschwander, U., Uknes, S., Vernooij, B., and Weymann, K. 1995. Signal transduction in systemic acquired resistance. Proc. Natl. Acad. Sci. U.S.A. 92:4202-4205.

Rybak, M., Minsavage, G. V., Stall, R. E., and Jones, J. B. 2009. Identification of Xanthomonas citri ssp. citri host specificity genes in a heterologous expression host. Mol. Plant Pathol. 10:249-262.

Schliehe, C., Flynn, E. K., Vilagos, B., Richson, U., Swaminathan, S., Bosnjak, B., Bauer, L., Kandasamy, R. K., Griesshammer, I. M., Kosack, L., Schmitz, F., Litvak, V., Sissons, J., Lercher, A., Bhattacharya, A., Khamina, K., Trivett, A. L., Tessarollo, L., Mesteri, I., Hladik, A., Merkler, D., Kubicek, S., Knapp, S., Epstein, M. M., Symer, D. E., Aderem, A., and Bergthaler, A. 2015. The methyltransferase Setdb2 mediates virus-induced susceptibility to bacterial superinfection. Nat. Immunol. 16:67-74.

Shi, Q., Febres, V. J., Jones, J. B., and Moore, G. A. 2015. Responsiveness of different citrus genotypes to the Xanthomonas citri ssp. citri-derived pathogen-associated molecular pattern (PAMP) flg22 correlates with resistance to citrus canker. Mol. Plant Pathol. 16:507-520.

Simko, I., and Piepho, H. P. 2012. The area under the disease progress stairs: Calculation, advantage, and application. Phytopathology 102:381-389.

Sun, L. R., Hao, F. S., Lu, B. S., and Ma, L. Y. 2010. AtNOA1 modulates nitric oxide accumulation and stomatal closure induced by salicylic acid in Arabidopsis. Plant Signal. Behav. 5:1022-1024.

Tatineni, S., Sagaram, U. S., Gowda, S., Robertson, C. J., Dawson, W. O., Iwanami, T., and Wang, N. 2008. In planta distribution of 'Candidatus
Liberibacter asiaticus' as revealed by polymerase chain reaction (PCR) and real-time PCR. Phytopathology 98:592-599.

Trivedi, P., Sagaram, U. S., Kim, J. S., Brlansky, R. H., Rogers, M. E., Stelinski, L. L., Oswalt, C., and Wang, N. 2009. Quantification of viable Candidatus Liberibacter asiaticus in hosts using quantitative PCR with the aid of ethidium monoazide (EMA). Eur. J. Plant Pathol. 124:553-563

Tsuda, K., Sato, M., Glazebrook, J., Cohen, J. D., and Katagiri, F. 2008 Interplay between MAMP-triggered and SA-mediated defense responses. Plant J. 53:763-775.

Vahling, C. M., Duan, Y., and Lin, H. 2010. Characterization of an ATP translocase identified in the destructive plant pathogen "Candidatus Liberibacter asiaticus". J. Bacteriol. 192:834-840.

Vanacker, H., Lu, H., Rate, D. N., and Greenberg, J. T. 2001. A role for salicylic acid and NPR1 in regulating cell growth in Arabidopsis. Plant J. 28:209-216.

Verberne, M. C., Brouwer, N., Delbianco, F., Linthorst, H. J., Bol, J. F., and Verpoorte, R. 2002. Method for the extraction of the volatile compound salicylic acid from tobacco leaf material. Phytochem. Anal. 13:45-50.

Vlot, A. C., Dempsey, D. A., and Klessig, D. F. 2009. Salicylic acid, a multifaceted hormone to combat disease. Annu. Rev. Phytopathol. 47: 177-206.

Wang, N., and Trivedi, P. 2013. Citrus Huanglongbing: A newly relevant disease presents unprecedented challenges. Phytopathology 103: 652-665.

Wang, Y., and Liu, J. H. 2012. Exogenous treatment with salicylic acid attenuates occurrence of citrus canker in susceptible navel orange (Citrus sinensis Osbeck). J. Plant Physiol. 169:1143-1149.

White-Stevens, R. H., and Kamin, H. 1972a. Studies of a flavoprotein, salicylate hydroxylase. I. Preparation, properties, and the uncoupling of oxygen reduction from hydroxylation. J. Biol. Chem. 247:2358-2370.

White-Stevens, R. H., Kamin, H., and Gibson, Q. H. 1972b. Studies of a flavoprotein, salicylate hydroxylse. I. Enzyme mechanism. J. Biol. Chem. 247:2371-2381.

Wildermuth, M. C., Dewdney, J., Wu, G., and Ausubel, F. M. 2001. Isochorismate synthase is required to synthesize salicylic acid for plant defence. Nature 414:562-565.

Wulff, N. A., Zhang, S., Setubal, J. C., Almeida, N. F., Martins, E. C., Harakava, R., Kumar, D., Rangel, L. T., Foissac, X., Bové, J. M., and Gabriel, D. W. 2014. The complete genome sequence of 'Candidatus Liberibacter americanus', associated with citrus Huanglongbing. Mol. Plant-Microbe Interact 27:163-176.

Yan, Q., Sreedharan, A., Wei, S., Wang, J., Pelz-Stelinski, K., Folimonova, S., and Wang, N. 2013. Global gene expression changes in Candidatus Liberibacter asiaticus during the transmission in distinct hosts between plant and insect. Mol. Plant Pathol. 14:391-404.

You, I. S., Ghosal, D., and Gunsalus, I. C. 1991. Nucleotide sequence analysis of the Pseudomonas putida PpG7 salicylate hydroxylase gene $(n a h G)$ and its $3^{\prime}$-flanking region. Biochemistry 30:1635-1641.

You, I. S., Murray, R. I., Jollie, D., and Gunsalus, I. C. 1990. Purification and characterization of salicylate hydroxylase from Pseudomonas putida PpG7. Biochem. Biophys. Res. Commun. 169:1049-1054.

Zhong, Y., Cheng, C. Z., Jiang, N. H., Jiang, B., Zhang, Y. Y., Wu, B., Hu, M. L., Zeng, J. W., Yan, H. X., Yi, G. J., and Zhong, G. Y. 2015. Comparative transcriptome and iTRAQ proteome analyses of citrus root responses to Candidatus Liberibacter asiaticus infection. PLoS One 10: e0126973.

Zhou, X., Yan, Q., and Wang, N. 2016. Deciphering the regulon of a GntR family regulator via transcriptome and ChIP-exo analyses and its contribution to virulence in Xanthomonas citri. Mol. Plant Pathol. 18:249-262.

Zou, H., Gowda, S., Zhou, L., Hajeri, S., Chen, G., and Duan, Y. 2012. The destructive citrus pathogen, 'Candidatus Liberibacter asiaticus' encodes a functional flagellin characteristic of a pathogen-associated molecular pattern. PLoS One 7:e46447. 